GLOBAL JOURNAL OF PURE AND APPLIED SCIENCES VOL. 24, 2018: 25-36

COPYRIGHTC BACHUDO SCIENCE CO. LTD PRINTED IN NIGERIA ISSN 1118-0579

\title{
EVALUATION OF LATERITIC SOIL USING 2-D ELECTRICAL RESISTIVITY METHODS AT ALAPOTI, SOUTHWESTERN NIGERIA
}

\section{ABEL GIWA USIFO, ADEWOLE JOHN ADEOLA, OLUMIDE OLUFEMI AKINNAWO AND KINGSLEY NOSAKHARE ONAIWU}

(Received 28 August 2017; Revision Accepted 20 October 2017)

\begin{abstract}
A 2-D resistivity survey was carried out in Alapoti, Ogun State, a sedimentary terrain of South-western Nigeria. This area lies between longitude $006^{\circ} 34^{\prime} 0^{\prime \prime} \mathrm{N}$ and $006^{\circ} 40^{\prime} 0^{\prime \prime} \mathrm{N}$ and latitude $003^{\circ} 2^{\prime} \mathrm{O}^{\prime \prime} \mathrm{E}$ and $003^{\circ} 6^{\prime} 0 " \mathrm{E}$. The wenner alpha electrode configuration was engaged through out in this study. Ten profiles were covered; five in the north-south direction, and the other five in the west-east direction.

To obtain a good 2-D picture of the subsurface, the coverage of the measurements must be 2-D as well. The distance between adjacent traverse is 25 metres. The data from each 2-D survey line was inverted independently with RES2DINV to give 2-D cross-sections with averages of 4.8 iteration and RMS error of $8.15 \%$. A contoured pseudosection conveys a qualitative two- dimensional resistivity variation with depth within the subsurface. The inversed model resistivity sections created models for the subsurface resistivity using an iterative smoothness constrained least square inversion and are interpreted to generate the subsurface geologic characteristics.

Results from 2-D inversed resistivity section showed that the second layer with resistivity value of about $200 \Omega \mathrm{m}$ to $600 \Omega \mathrm{m}$ and thickness of about $4.0 \mathrm{~m}$ is composed of lateritic clay. The third layer is made up of moderate laterite having a thickness of about $3.0 \mathrm{~m}$ and apparent resistivity ranging from $600 \Omega \mathrm{m}$ to $1,000 \Omega \mathrm{m}$, while the fourth layer of apparent resistivity value $1,000 \Omega \mathrm{m}$ to $1,500 \Omega \mathrm{m}$ is laterite but rich in sand and it is located at a deep of about $12.0 \mathrm{~m}$.
\end{abstract}

KEYWORDS: Laterite, Inverse model resistivity, 2-D, Iteration, Wenner array.

\section{INTRODUCTION}

The purpose of this study is to search for laterite which is of immense economic value. .Laterites are soil types rich in iron and aluminum, formed in hot and wet tropical areas (Tardy, 1997). Nearly all laterites are rusty-red because of iron oxides. They develop by intensive and long-lasting weathering of the underlying parent rock. Tropical weathering is a prolonged process of chemical weathering which produces a wide variety in the thickness, grade, chemistry and ore mineralogy of the resulting soils (Tardy, 1997). The majority of the land areas with laterites ore are between the tropics of Cancer and Capricorn (Tardy, 1997).

Historically, laterite was cut into brick-like shapes and used in monument building (Norton, 2000). Since the mid-1970s trial sections of bituminoussurfaced, low-volume roads have used laterite in place of stone as a base course. Thick laterite layers are porous and slightly permeable, so the layers can function as aquifers in rural areas. Locally available laterites are used in an acid solution, followed by precipitation to remove phosphorus and heavy metals at sewage treatment facilities (Norton, 2000).

Laterites are a source of aluminum ore; the ore exists largely in clay minerals and the hydroxides, gibbsite, boehmite, and diaspore, which resembles the composition of bauxite (Norton, 2000). In Northern Ireland they once provided a major source of iron and aluminum ores (Prudence, 1996). Laterite ores also were the early major source of nickel. Francis Buchanan-Hamilton first described and named a laterite formation in southern India in 1807 (Norton, 2000). He named it laterite from the Latin word later, which means a brick; this rock can easily be cut into brick-shaped blocks for building (Norton, 2000). Laterites can be either soft or easily broken into smaller pieces, or firm and physically resistant. Laterites are formed from the

Abel Giwa Usifo, Department of Physical and Earth Sciences, Crawford University, Km 8, Atan-Agbara Road, Igbesa, Ogun State, Nigeria.

Adewole John Adeola, Department of Physical and Earth Sciences, Crawford University, Km 8, Atan-Agbara Road, Igbesa, Ogun State, Nigeria.

Olumide Olufemi Akinnawo, Department of Physical and Earth Sciences, Crawford University, Km 8, Atan-Agbara Road, Igbesa, Ogun State, Nigeria.

Kingsley Nosakhare Onaiwu, Department of Physical and Earth Sciences, Crawford University, Km 8, Atan-Agbara Road, Igbesa, Ogun State, Nigeria. 
leaching of parent sedimentary (sandstones, clays, lime stones); metamorphic rocks (schists, gneisses, migmatites); igneous rocks (granites, basalts, gabbros, peridotites); and mineralized proto-ores; which leaves the more insoluble ions, predominantly iron and aluminum (Norton, 2000). An essential feature for the formation of laterite is the repetition of wet and dry seasons. The mineralogical and chemical compositions of laterites are dependent on their parent rocks. Laterites vary significantly according to their location, climate and depth. Laterites are widely used to build blocks, build roads, as aquifers in water supply, water treatment etc. (Adekunle A. et. al).

\section{Geological Setting and Stratigraphy of Dahomey Basin}

Alapoti and its environs is located in the Southwestern part of Nigeria and falls within the Dahomey Basin. The Dahomey basin extends considerably along the continental margin of the Gulf of Guinea, westward from the Volta basin in Ghana to the Okitipupa ridge in Nigeria. It is a marginal sag basin (Kingston, 1983, Okosun,1990) or a marginal pull apart basin (Klemme, 1975), whose development in the Mesozoic (Jurassic Cretaceous) is associated with the separation of the African and South American lithospheric plates (Burke, 1971). It is bounded on the west by faults and other tectonic structures associated with the landward extension of Romanche fracture limit. The eastern limit is marked by the Benin Hinge line, a major fault structure that marked the western limit of the Niger Delta Basin. To the east of the Benin Hinge line is the Okitipupa Ridge (Adegoke, 1962, Billman 1976, Omatsola and Adegoke 1981).

Sedimentation did not start until the terminal stages of the Cretaceous period. The major marine transgression in the Benin flank of the basin occurred during Maestrician when the sediments constituting the Abeokuta formation were deposited. The development of this basin is associated with tectonics that accompanied the opening of the Atlantic Ocean (Adegoke et al, 1980). Following faulting and basement subsidence varying thickness of continental sediments that were locally derived from the weathering of the adjourning crystalline basement rocks, were deposited in the basin. These pre-drift sediments are preserved in a number of boreholes (Omatsola and Adegoke 1980, 1981). During the Santonian tectonic episode, the basement rocks were block faulted forming a crustal subsidence. This tectonism initiated the widespread marine transgression of the maestrichian period in the basin. The nature and the thickness of sediments accumulation in the basin were controlled by the degree of faulting and subsidence. The oldest dated sediments on shore of the Dahomey basin consist of cretaceous grits and sandstone with interbedded mudstone. They are overlain by finer, detrital, sandstones, siltstones and shales of transitional nature. The youngest sediments are marginal to fully marine sands and shales of Maestrichtian age.

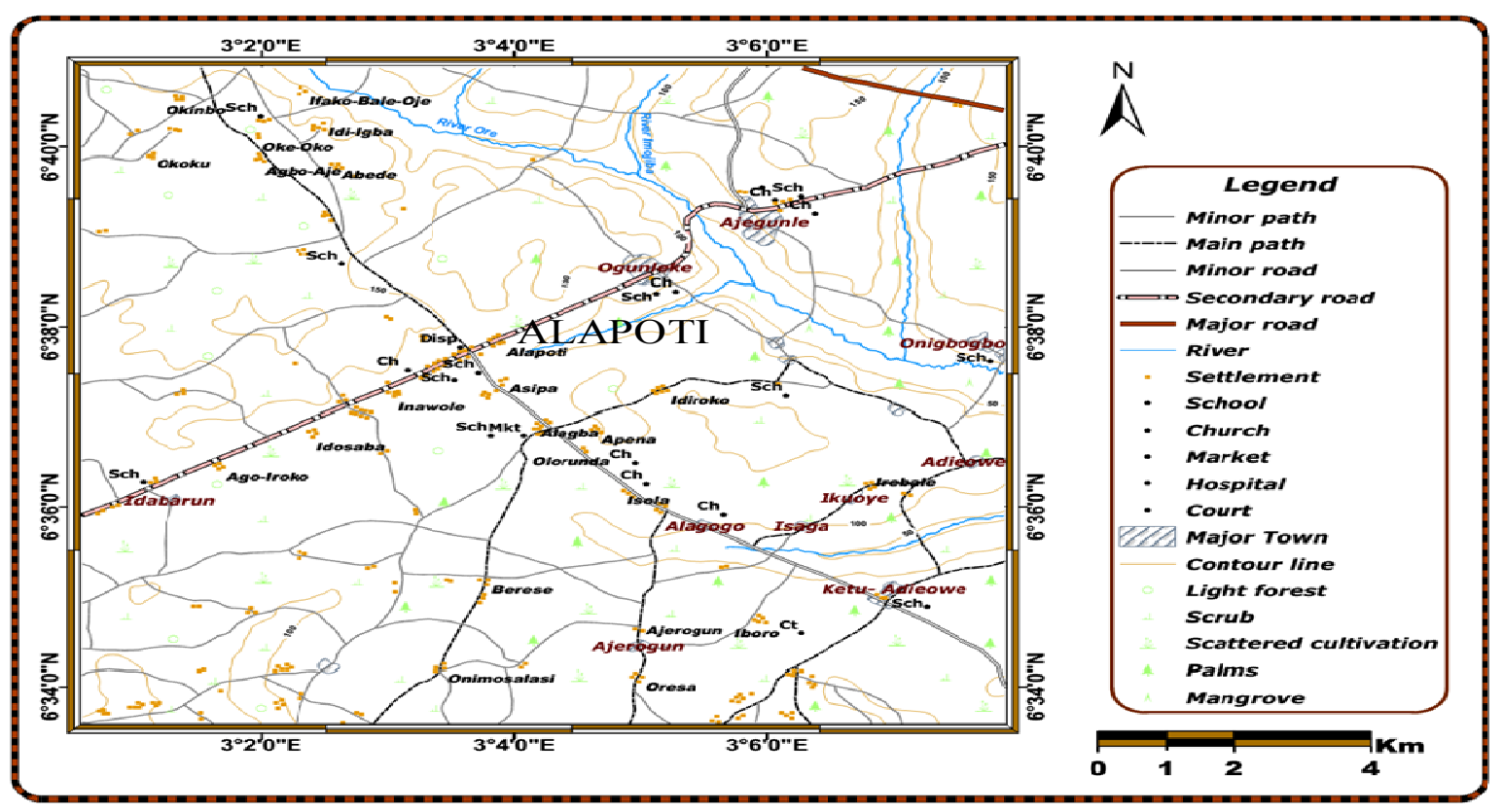

Figure 1: Location map of the study area 


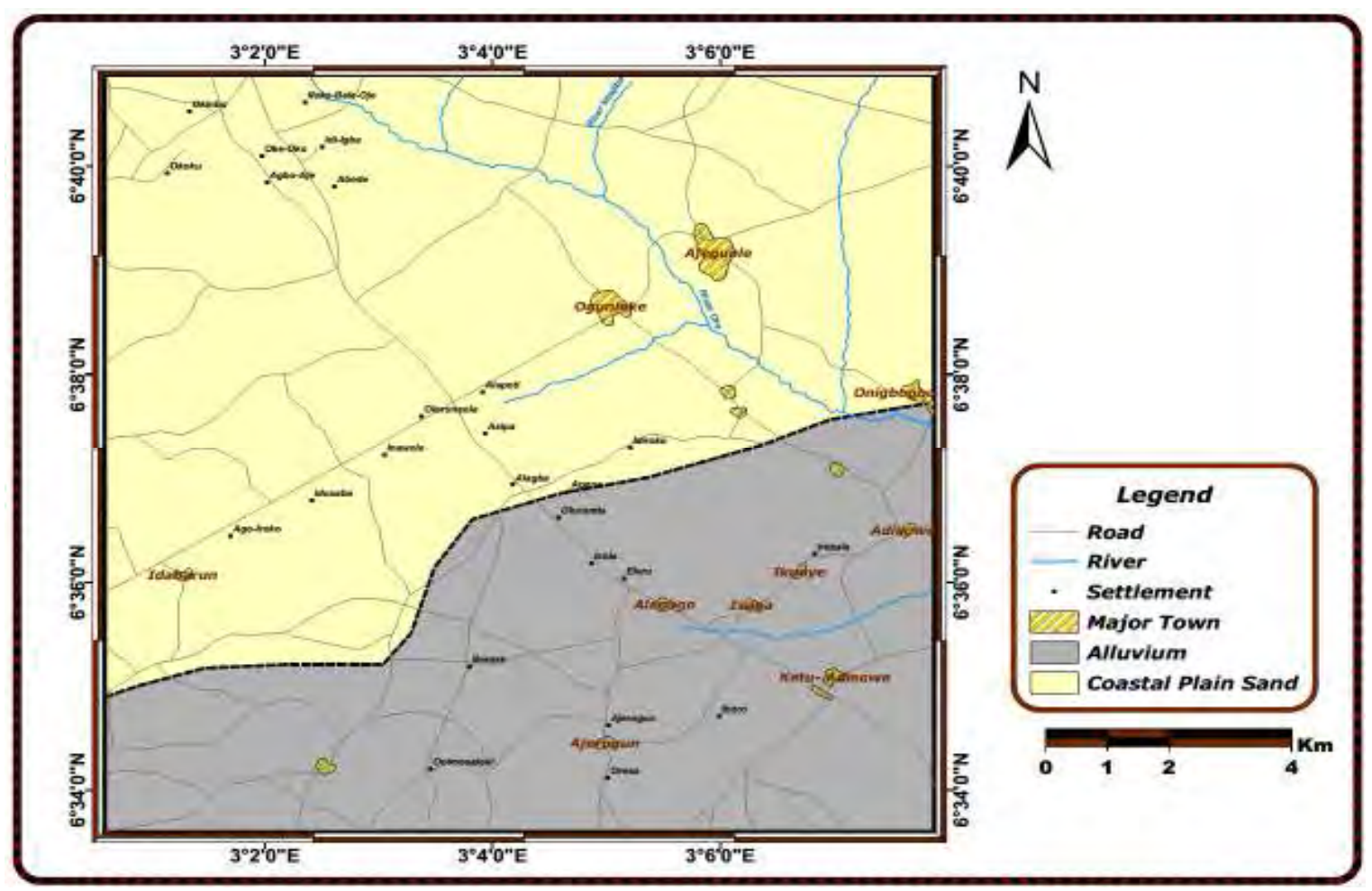

Figure 2: Geological map of the study area

\section{METHODOLOGY}

One of the new developments in recent years is the use of 2-D electrical imaging/tomography surveys to map areas with moderately complex geology (Griffiths and Barker 1993). Such surveys are usually carried out using a large number of electrodes, 25 or more, connected to a multi-core cable. A laptop microcomputer together with an electronic switching unit is used to automatically select the relevant four electrodes for each measurement. At present, field techniques and equipment to carry out 2-D resistivity surveys are fairly well developed. The necessary field equipment is commercially available from a number of international companies. Some institutions have even constructed "home-made" manually operated switching units at a nominal cost by using a seismic cable as the multi-core cable (Dahlin and Loke, 1998).

Two dimensional resistivity surveys are usually carried out with a number of electrodes connected to a multicore cable. One such a system is the Multi Abem Terrameter System where each electrode along the cable can be used as a current or potential electrode (Griffiths et. al., 1990; Griffiths and Barker, 1993). The smoothness-constrained least squares method was used. This consists of a number of 2-D rectangular blocks. We adopted the model used by (Barker, 1992) were the blocks are equal in number to the data points in the apparent resistivity pseudosection and are arranged in similar manner. The depths to the centres of the interior block are placed at the median depth of investigation (Edwards, 1977) for different electrode spacings used. The median depth of investigation is about 0.5 times the electrode spacing for the wenner array. The smoothness- constrained modification to the Gauss-Newton method (deGroot-Hedlin and Constable,
1990) leads to the following system of normal equations:

$$
\left(J_{i}^{T} J_{i}+\lambda_{i} C^{T} C\right) p_{i}=J_{i}^{T} g_{i}
$$

Where $\mathrm{i}$ is the iteration number, $\mathrm{j}_{\mathrm{i}}$ is the Jacobian matrix of partial derivatives, $g_{i}$ is the discrepancy vector which contains the the differences between logarithms of the measured and calculated apparent resistivity values, $\lambda_{i}$ is the damping factor and $p_{i}$ is the perturbation vector to the model parameter for the ith iteration.

\section{RESULTS AND DISCUSSION}

\section{Traverse Line One}

Figure 3 with orientation approximately along the northsouth direction represents an inverse model resistivity section for traverse line one and shows variation in resistivity along the traverse line with depth. The section capture a low resistivity material interpreted to be lateritic clay with resistivity range of $383 \Omega \mathrm{m}$ to $549 \Omega \mathrm{m}$ as the topsoil material (Barker et. al, 1992 and Kearey et. al, 2002). The topsoil material consists of moderately consistent layer of thickness of approximately $6.0 \mathrm{~m}$. The topsoil underlain by five tiny layers which spread across the traverse, having resistivity values ranging from about $549 \Omega \mathrm{m}$ to $722 \Omega \mathrm{m}$ is laterite. These layers extend from a depth of $6.50 \mathrm{~m}$ and beyond. The seventh to twelfth layer form a dome-like structure at northern side of the traverse. It is at a depth of about $8.0 \mathrm{~m}$ with an apparent resistivity ranging from about $722 \Omega \mathrm{m}$ to1350 $\Omega \mathrm{m}$ indicating the presence of lateritic sand/wet sand. 


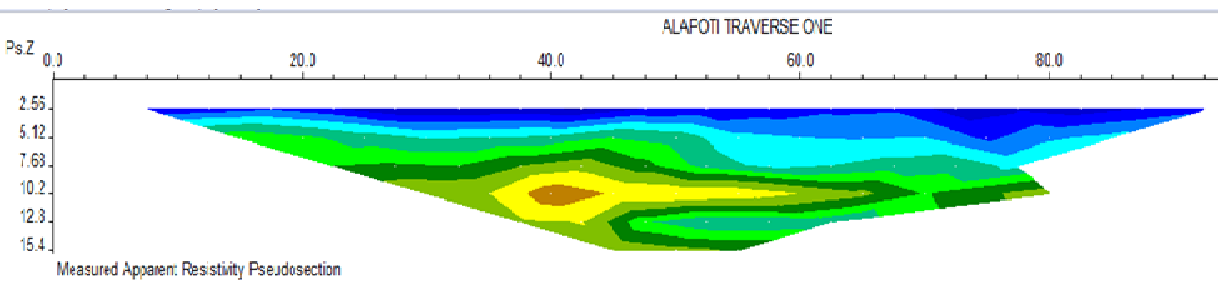

(a)
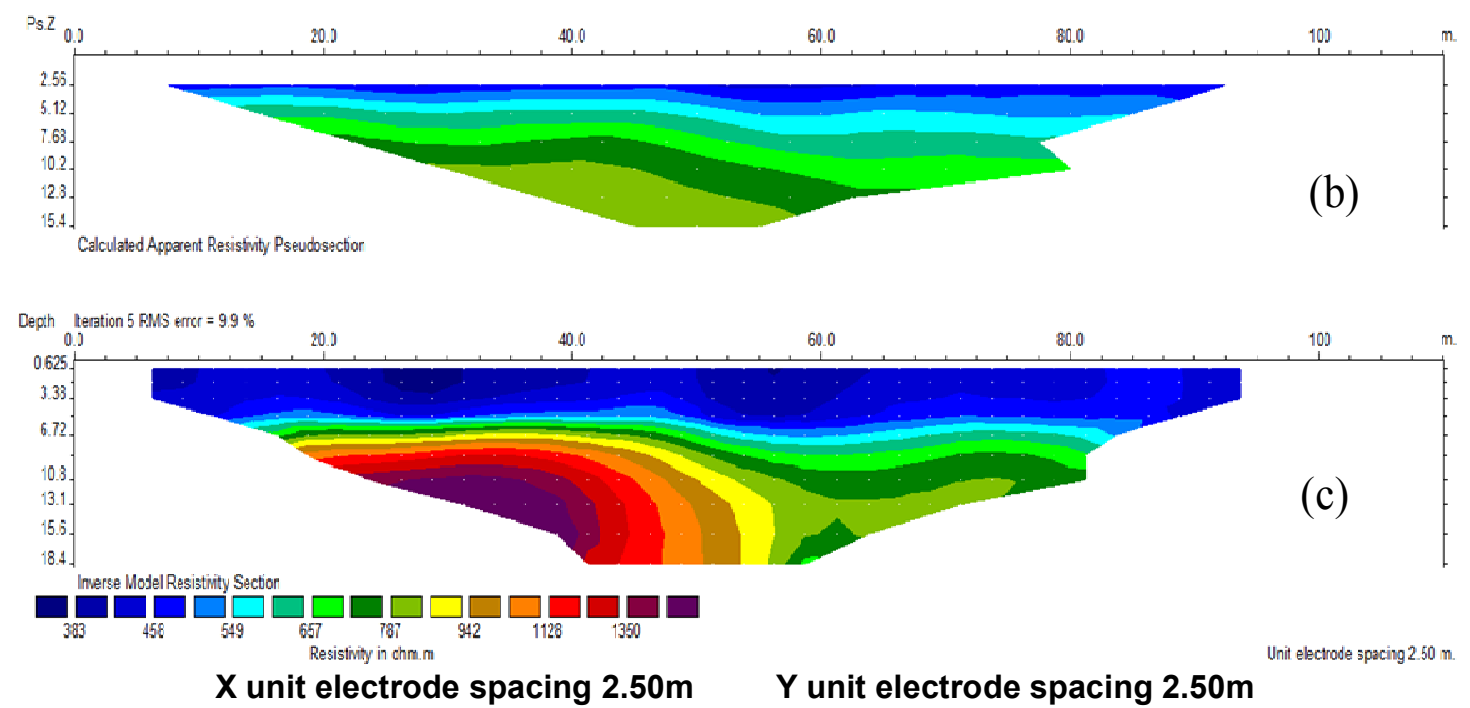

Figure 3: (a) The measured apparent resistivity pseudosection, (b) calculated apparent resistivity pseudosection and (c) inverse model resistivity section for traverse 1.

\section{Traverse Line Two}

Figure 4 shows the inversed resistivity section for traverse line two with orientation running in the northsouth direction. The image line represents the resistivity variation with depth across the line and delineated low resistive topsoil which is characterized to be lateritic clay with resistivity values range of about $444.0 \Omega \mathrm{m}$ to 609.0 $\Omega \mathrm{m}$. The second layer to the eighth layer delineated is presumed to be laterite with resistivity values ranging from $609.0 \Omega \mathrm{m}$ to1, $000 \Omega \mathrm{m}$. These spread across the traverse. The ninth, tenth and eleventh layers depicts lateritic sand/wet sand with resistivity values ranging from $1,000 \Omega \mathrm{m}$ to $1400 \Omega \mathrm{m}$. It is found at a depth of about $10.0 \mathrm{~m}$ forming a dome-like structure within a horizontal distance of about $30.0 \mathrm{~m}$ to $52.0 \mathrm{~m}$ in the northern side of the traverse.

\section{Traverse Line Three}

The inversed model resistivity section for traverse line three (figure 5) with orientation approximately in the north-south direction clearly shows pockets of low resistivity material suspected to be lateritic clay which forms the topsoil. It has apparent resistivity values of range $479 \Omega \mathrm{m}$ to $628 \Omega \mathrm{m}$. The topsoil material is underlain by high resistive materials of apparent resistivities values of range $628 \Omega \mathrm{m}$ to $1019 \Omega \mathrm{m}$ at a vertical distance of $6.72 \mathrm{~m}$ to $13.10 \mathrm{~m}$. The last layer depicts lateritic sand/wet sand with apparent resistivity greater than $1019 \Omega \mathrm{m}$. It slopes northward and southward at the centre of the traverse. The geological descriptions are compared to the approximate resistivity ranges described by (Kearey et.al, 2002). 

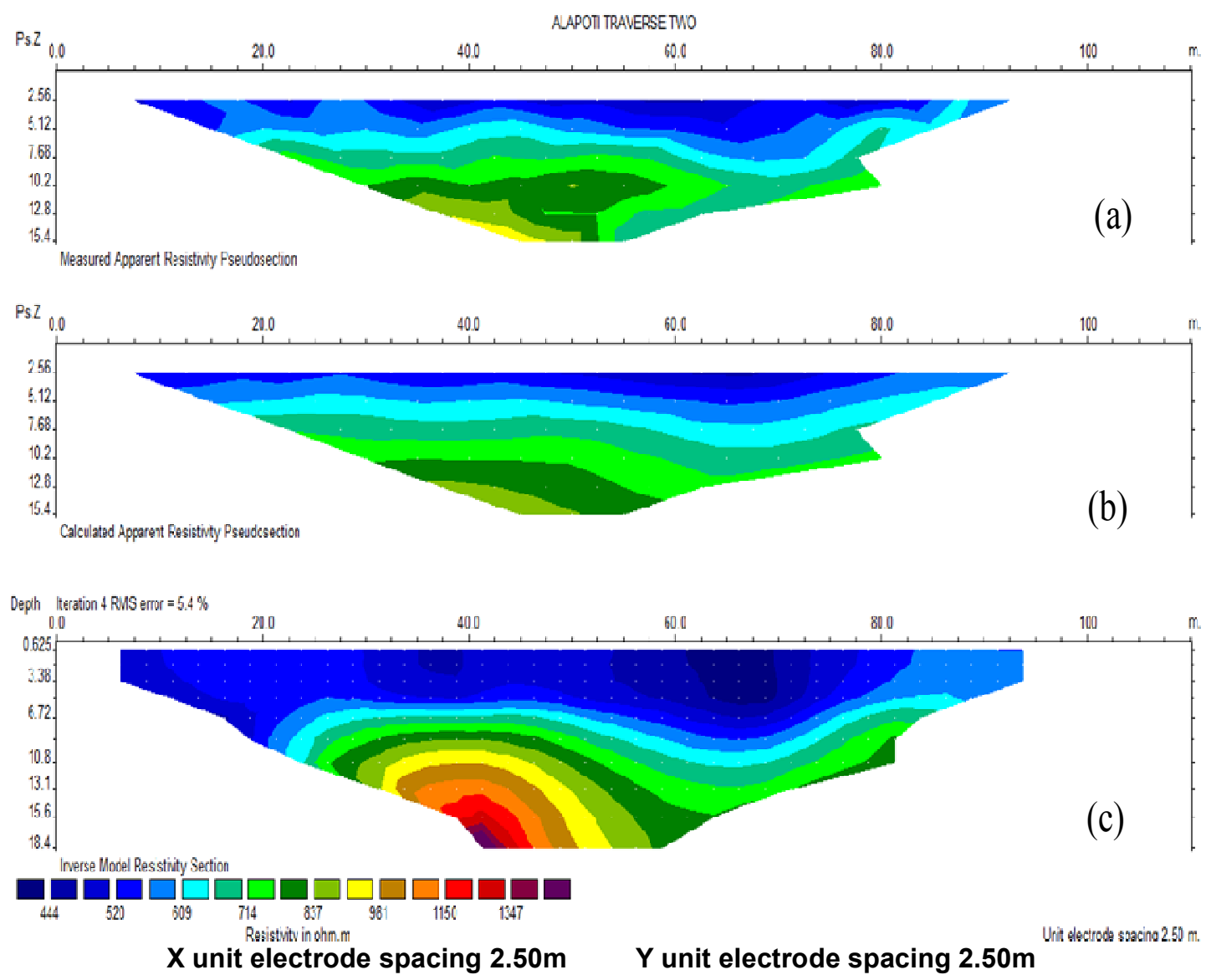

Figure 4: (a) The measured apparent resistivity pseudosection, (a)calculated apparent resistivity pseudosection and (a) inverse model resistivity section for traverse 2

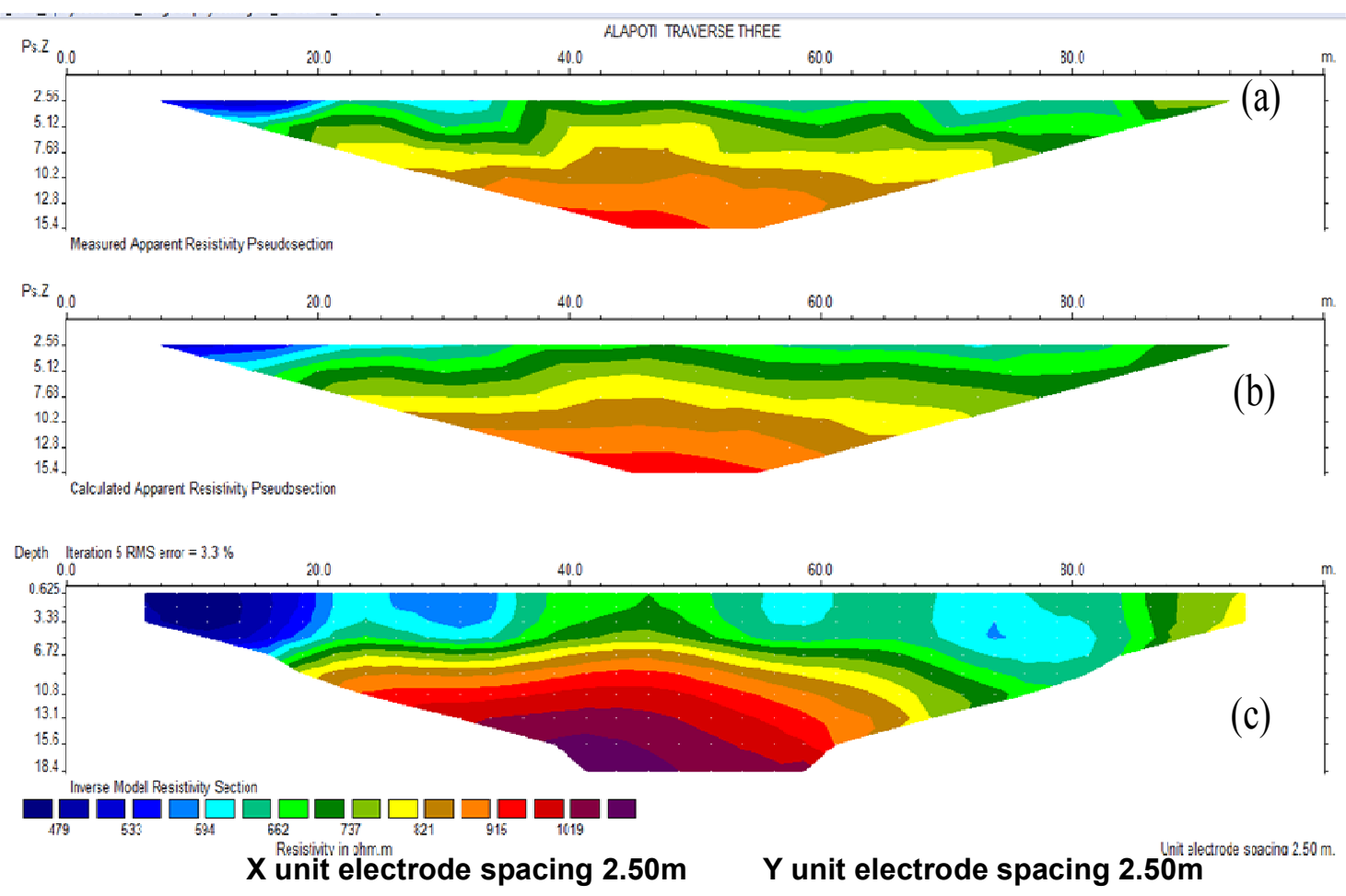

Figure 5: (a) The measured apparent resistivity pseudosection, (a) calculated apparent resistivity pseudosection and (c) inverse model resistivity section for traverse 3. 


\section{Traverse Line Four}

The inversed model resistivity section along traverse line four (figure 6) showed the resistivity variation along the traverse line with depth. The low resistive portion on the horizontal distance of about $38.0 \mathrm{~m}$ to $72.0 \mathrm{~m}$ which depicts lateritic clay is the top soil. It has an apparent resistivity ranging from about $215.0 \Omega \mathrm{m}$ to $494.0 \mathrm{~m}$. This is overlain at the extreme north and south of the traverse by a high resistive lateritic material of apparent resistivity above $500.0 \mathrm{~m}$. Beneath the top soil is a section having resistivity values of range $494.0 \Omega \mathrm{m}$ to $1427.0 \Omega \mathrm{m}$, and it indicates lateritic sand with an average thickness of about $6.0 \mathrm{~m}$. Underneath is a layer with apparent resistivity greater than $4,000 \Omega \mathrm{m}$, forming a small spot in the northern side of the traverse at a depth of about $17.50 \mathrm{~m}$ below the surface which is presumed to be dry sand/porous limestone.

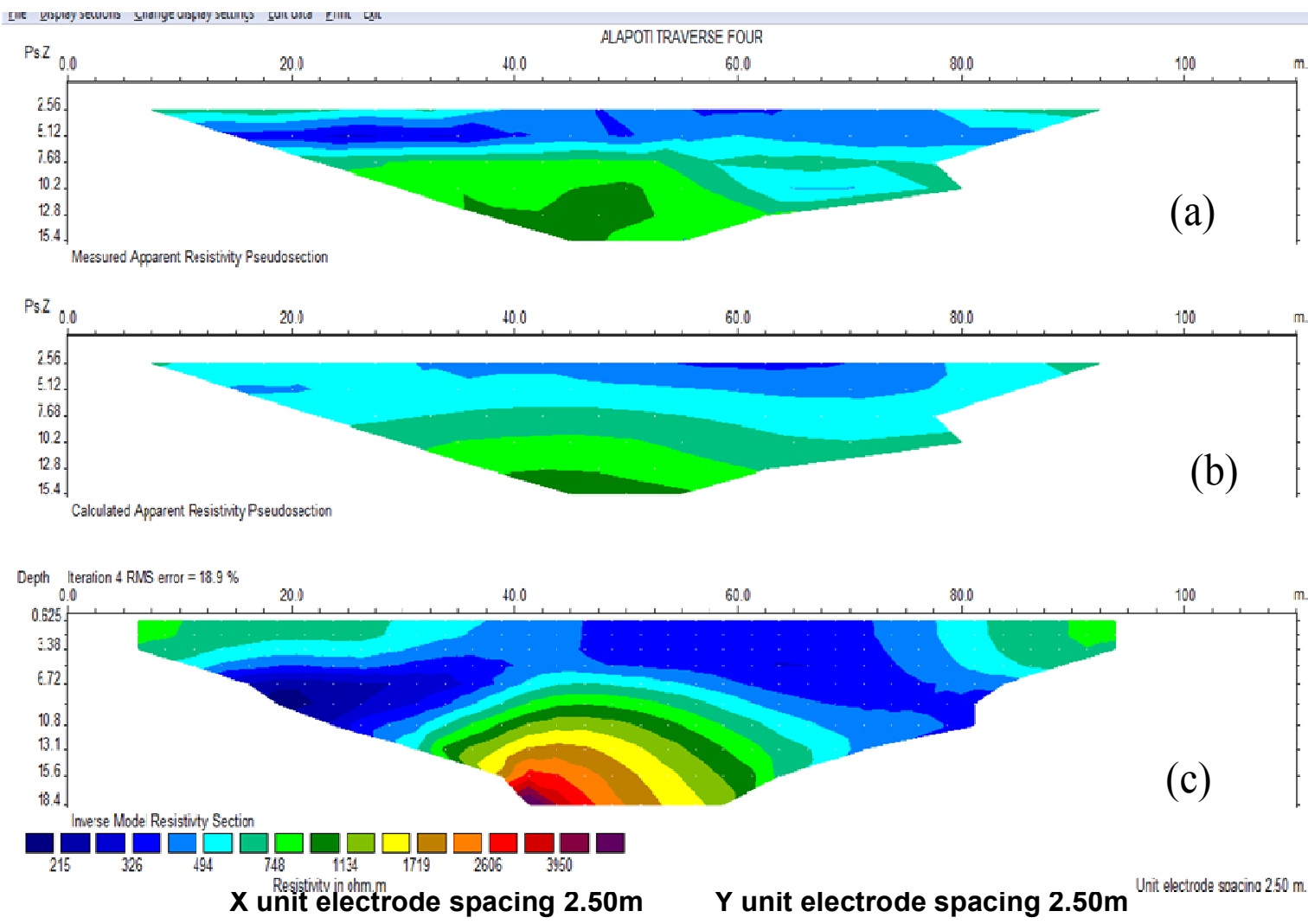

Figure 6: (a) The measured apparent resistivity pseudosection, (b)calculated apparent resistivity pseudosection and (c) inverse model resistivity section for traverse 4.

\section{Traverse Line Five}

The inversed model resistivity section for traverse line five (figure 7) with orientation along the north-south direction of the study area, and the image line show a moderate resistive topsoil material with apparent resistivity values ranging from $559.0 \Omega \mathrm{m}$ to $1014.0 \mathrm{~m}$ $\Omega \mathrm{m}$. It shows the presence of laterite. Underlain this layer is a high resistive material composed of lateritic sand with apparent resistivity values ranging from $1014.0 \Omega \mathrm{m}$ to $1,600.0 \Omega \mathrm{m}$. The last layer is composed of a high resistive material made up of dry sand with apparent resistivity greater than $1,500 \Omega \mathrm{m}$. It appears as a little spot at the northern side of the traverse. 


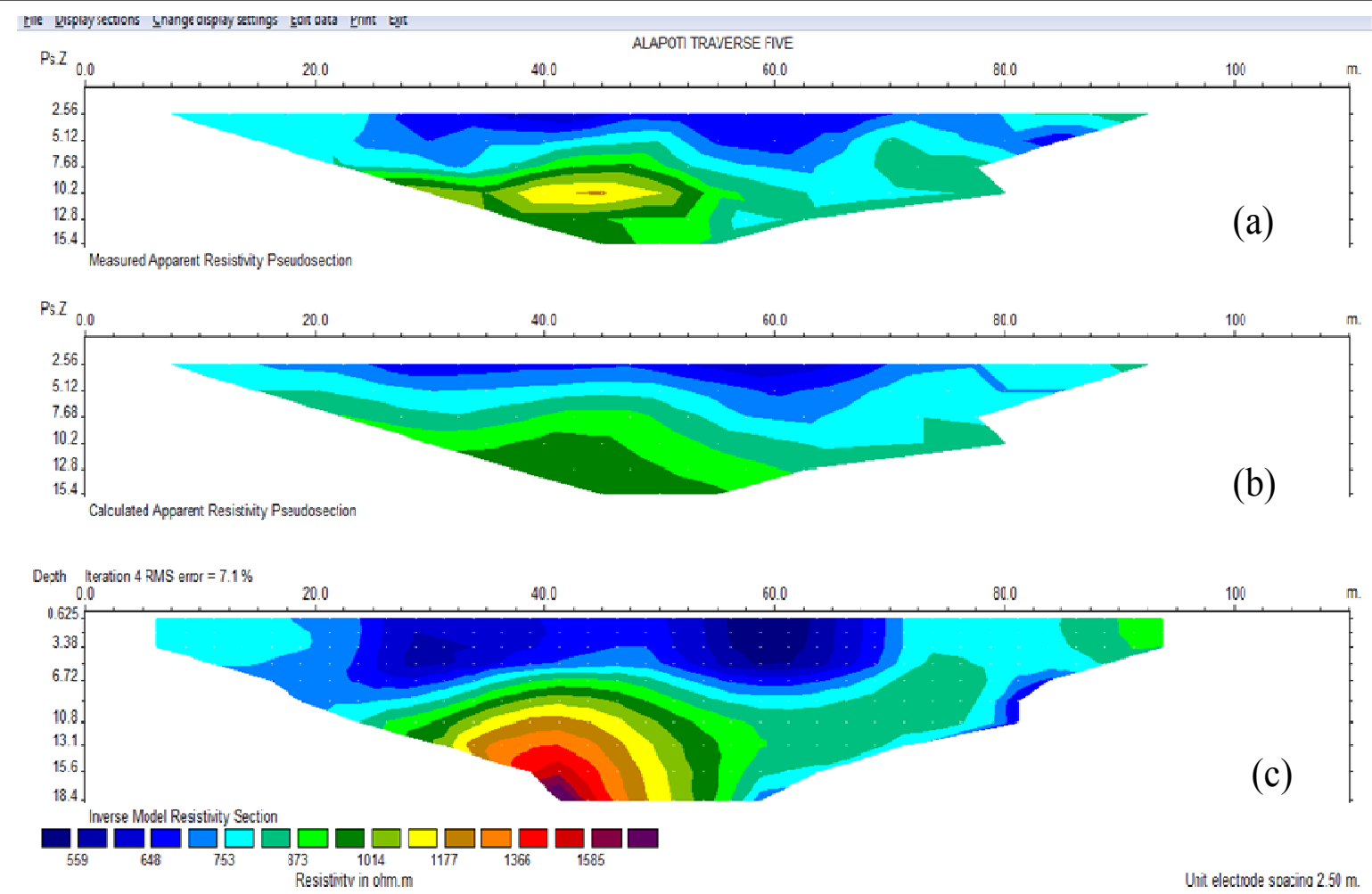

\section{$X$ unit electrode spacing $2.50 \mathrm{~m} \quad Y$ unit electrode spacing $2.50 \mathrm{~m}$}

Figure 7: (a) The measured apparent resistivity pseudosection, (a)calculated apparent resistivity pseudosection and (c) inverse model resistivity section for traverse 5.

\section{Traverse Line Six}

Figure 8 shows the inversed model resistivity section along traverse line six representing the subsurface resistivity variation with depth along the traverse line and runs from the western to eastern parts of the study area. The top layer delineated depicts a highly inhomogeneous top soil of apparent resistivity values ranging from about353.0 $\Omega \mathrm{m}$ to $700.0 \Omega \mathrm{m}$, and it is made up of lateritic clay/laterite. The minimum thickness of the top soil (which is at the middle of the traverse) is approximately $6.0 \mathrm{~m}$.It is underlain by highly resistive mini- layers but of apparent resistivity values less than $1,000 \Omega \mathrm{m}$ and it depicts laterite. The dome-like more highly resistive layer with apparent resistivity values greater than $1,000 \Omega m$ is composed of lateritic sand.

\section{Traverse Line Seven}

Figure 9 represents the inversed model resistivity section along traverse line seven with orientation approximately in the west - east direction and represents resistivity variation with depth along the traverse line. The top soil is inhomogeneous, and at a horizontal distance from $0.0 \mathrm{~m}$ to $16.0 \mathrm{~m}$ and from $63.0 \mathrm{~m}$ to $75.0 \mathrm{~m}$ along the traverse are pockets of low resistive clayey sand /sandy clay with apparent resistivity values ranging from about $130.0 \Omega \mathrm{m}$ to $260.0 \Omega \mathrm{m}$. From the surface (at the middle of the traverse) to about a depth of $7.0 \mathrm{~m}$ are high resistive materials suspected to be lateritic clay with apparent resistivity ranging from about $260.0 \Omega \mathrm{m}$. to $625.0 \Omega \mathrm{m}$. Underlain this, is a layer of about $3.0 \mathrm{~m}$ thick within a horizontal distance of $20.0 \mathrm{~m}$ to $70.0 \mathrm{~m}$ and at a depth of about $7.0 \mathrm{~m}$ with apparent range of about $625.0 \Omega \mathrm{m}$ to $1,000 \Omega \mathrm{m}$ which depicts laterite. A dome-like structure sloping eastward with apparent resistivity value range of $1,000 \Omega \mathrm{m}$ to 1,500 $\Omega \mathrm{m}$, and at a depth of about $13.0 \mathrm{~m}$ indicates lateritic sand. The next layer with apparent resistivity values ranging from $1,800 \Omega m$ to $2,000 \Omega m$ indicates wet sand, while the last layer with apparent resistivity greater than 2,000 $\Omega \mathrm{m}$ depicts dry sand and its appeared as a tiny spot on the western side of the traverse at a depth of about $17.0 \mathrm{~m}$. 

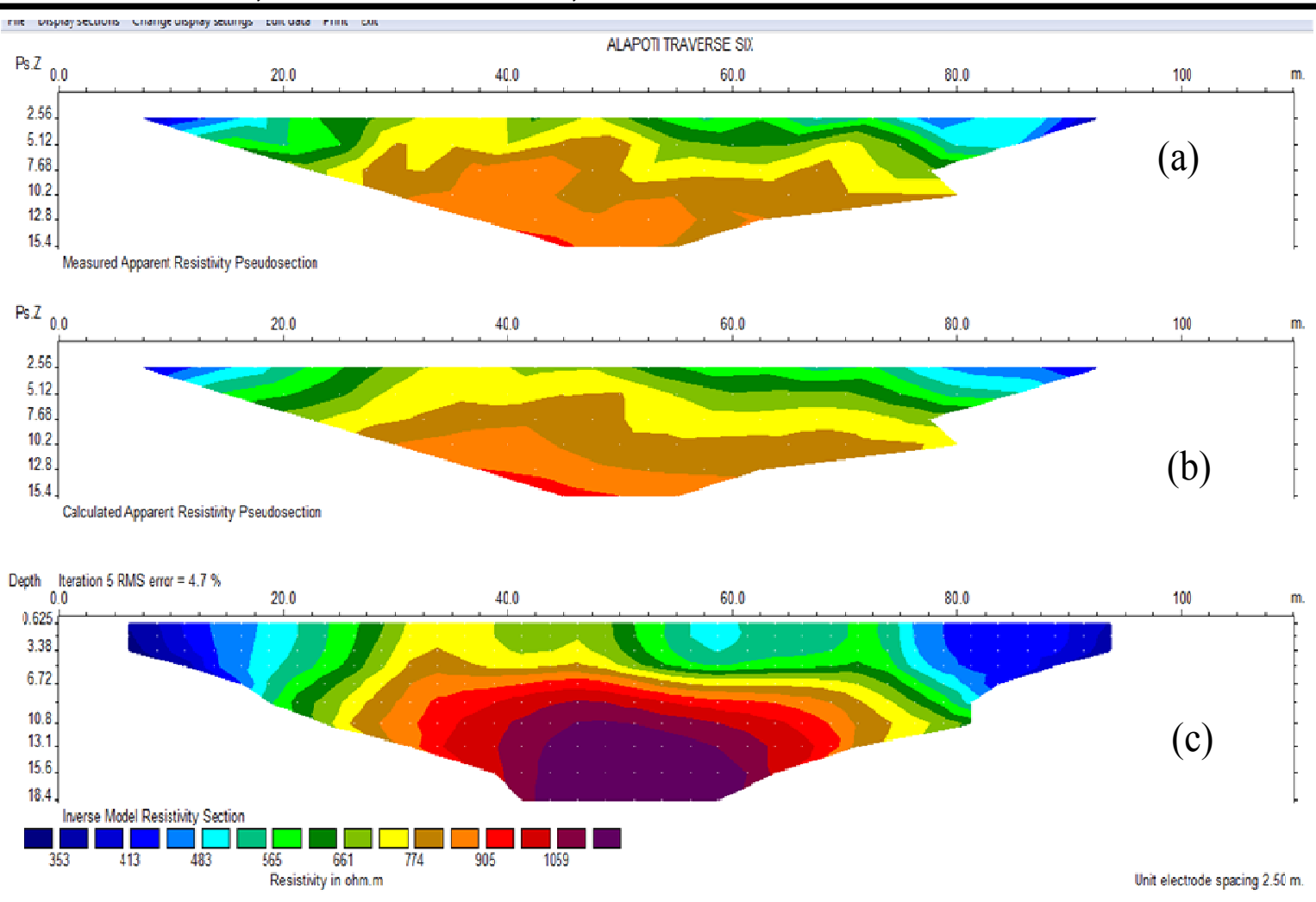

\section{$X$ unit electrode spacing $2.50 \mathrm{~m} \quad Y$ unit electrode spacing $2.50 \mathrm{~m}$}

Figure 8: (a) The measured apparent resistivity pseudosection, (b)calculated apparent resistivity pseudosection and (c) inverse model resistivity section for traverse 6.

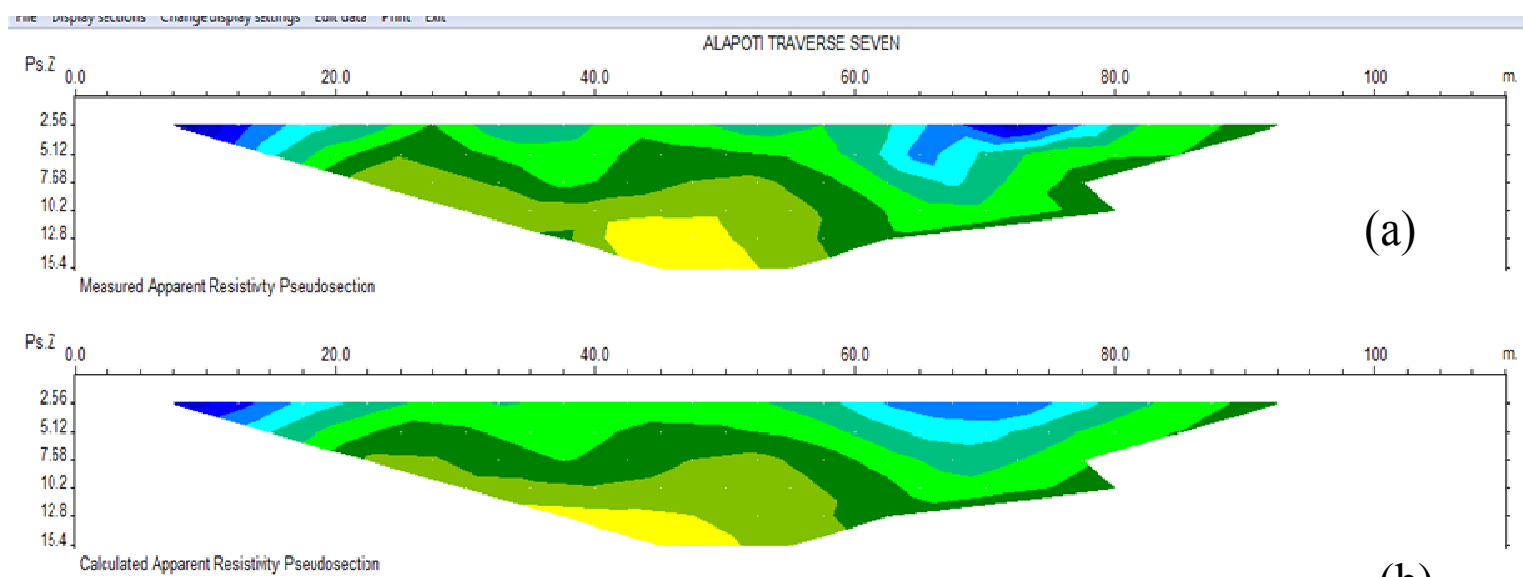

(b)

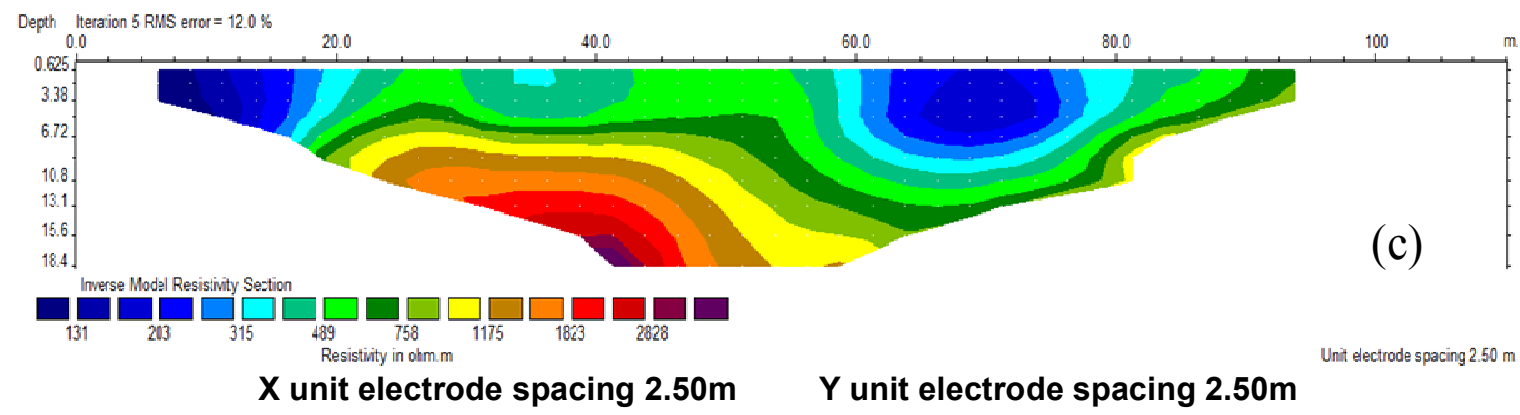

Figure 9: (a) The measured apparent resistivity pseudosection, (b) calculated apparent resistivity pseudosection and (c) inverse model resistivity section for traverse 7. 


\section{Traverse Line Eight}

The inversed model resistivity section along traverse line eight with orientation along west - east direction (figure 10) also shows the resistivity variation along the traverse line with depth. The top soil is relatively highly inhomogeneous with apparent resistivity values ranging from about350.0 $\Omega \mathrm{m}$ to $650.0 \Omega \mathrm{m}$ and it is composed of lateritic clay. Beneath this top soil at a depth of about $8.0 \mathrm{~m}$ are five tiny layers with apparent resistivity values ranging from about $650.0 \Omega \mathrm{m}$ to $1,000 \Omega \mathrm{m}$ which depicts laterite. Sloping eastward at a depth of about $14.0 \mathrm{~m}$ are high resistive materials presumed to be sand on the west of the traverse with apparent resistivity greater than 1,700

$\Omega m$
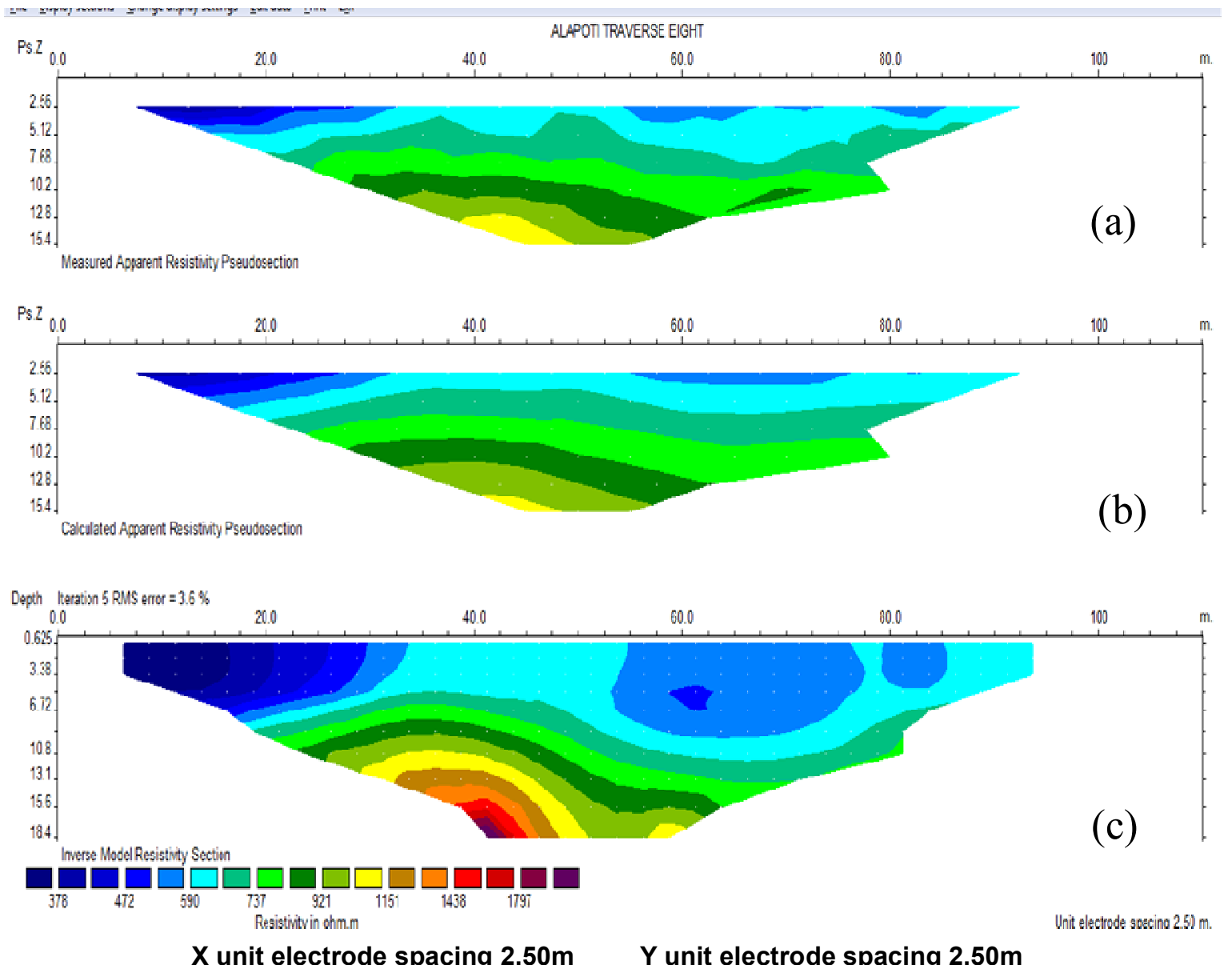

Figure 10: (a) The measured apparent resistivity pseudosection,(b)calculated apparent resistivity pseudosection and (b) inverse model resistivity section for traverse 8 .

\section{Traverse Line Nine}

Figure 11 with orientation trending approximately in the west-east direction represents an inverse model resistivity section for traverse line nine which also shows the resistivity variation along the traverse line with depth. The section captures another very high inhomogeneous top soil. From a horizontal distance of about $0.0 \mathrm{~m}$ to $27.0 \mathrm{~m}, 42.0 \mathrm{~m}$ to $50.0 \mathrm{~m}$, and also about $52.0 \mathrm{~m}$ to $66.0 \mathrm{~m}$ are low resistive material suspected to be lateritic clay with apparent resistivity values range of about $450.0 \Omega \mathrm{m}$ to $650.0 \Omega \mathrm{m}$. Between and underlying this, is a high resistive material with apparent resistivity values ranging from $650.0 \Omega \mathrm{m}$ to $770.0 \Omega \mathrm{m}$ indicating the presence of laterite. At a depth ranging from $10.0 \mathrm{~m}$ in the west to $7.0 \mathrm{~m}$ in the east of the traverse are seven layers with materials suspected to be lateritic sand. In the same vein, a tiny spot at the western side of the traverse at a depth of about $17.0 \mathrm{~m}$ with apparent resistivity values greater than $1,460 \Omega$ m depicts sand. 

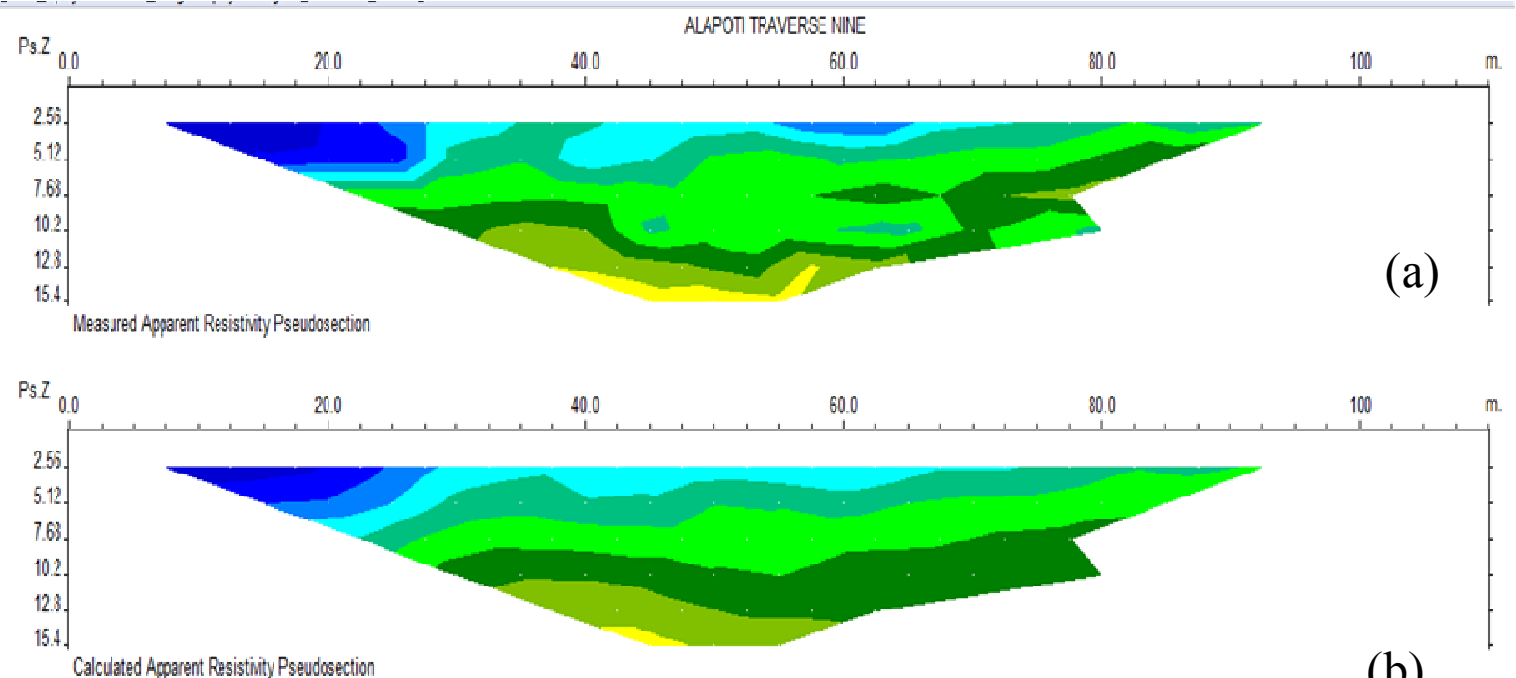

Calcuated Acparent Resistinity Pseudosection

(b)

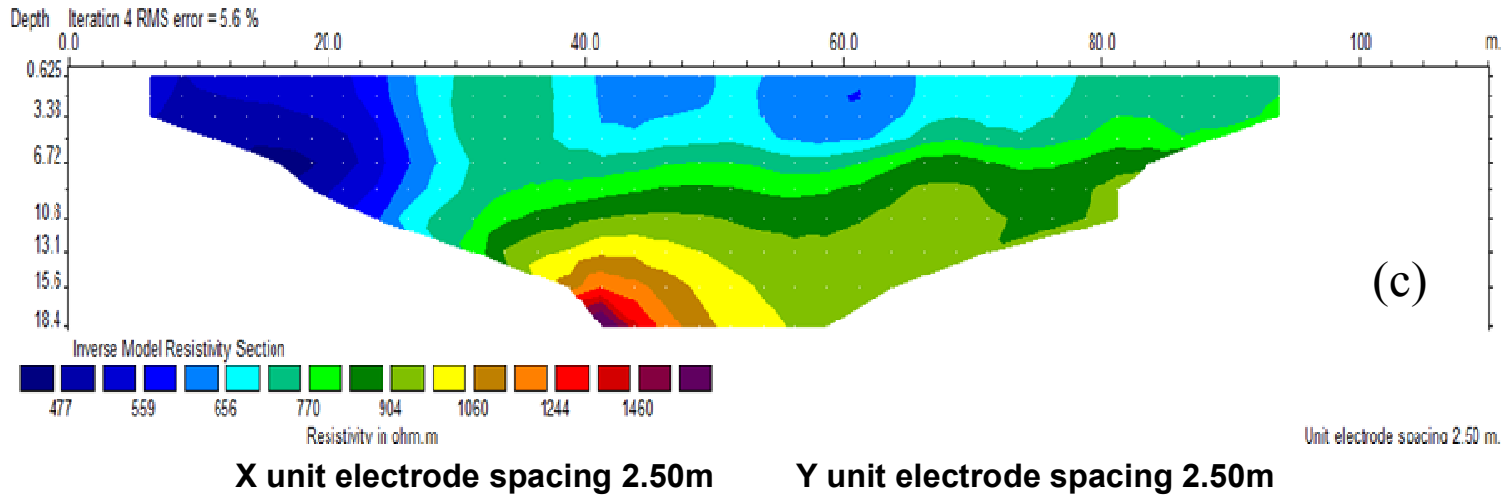

Figure 11: (a) The measured apparent resistivity pseudosection, (b) calculated apparent resistivity pseudosection and (c) inverse model resistivity section for traverse 9.

\section{Traverse Line Ten}

Traverse line ten (figure 12) shows the inverted resistivity section representing the resistivity variation with depth along the image line. Orientation of the traverse line is approximately along west - east direction and delineated the topsoil layer with resistivity value range of $100.0 \Omega m-310.0 \Omega m$ depicting sandy clay/ clayey sand. It spreads eastward to a distance of $74.0 \mathrm{~m}$ along the traverse. Underlain is a relatively high resistive layer with apparent resistivity values range of about $310.0 \Omega \mathrm{m}$ to $546.0 \Omega \mathrm{m}$ which indicates lateritic clay .At a depth of about $9.0 \mathrm{~m}$ is a third layer with apparent resistivity values ranging from $546.0 \Omega \mathrm{m}$ to $909.0 \Omega \mathrm{m}$, and it contain laterite. The fourth layer has an apparent resistivity values range of about $909.0 \Omega \mathrm{m}$ to $1,500 \Omega \mathrm{m}$ indicating the presence of lateritic sand. Beneath this, is a sloping layer located at a depth of about $15.0 \mathrm{~m}$ below the surface with an apparent resistivity values ranging from $1,500 \Omega \mathrm{m}$ to $2,500 \Omega \mathrm{m}$ and it is suspected to be wet sand. The last layer appears on the west side of the traverse at a horizontal distance of about $37.0 \mathrm{~m}$ to $50.0 \mathrm{~m}$ and a vertical distance of about $15.0 \mathrm{~m}$. It delineates dry sand. 

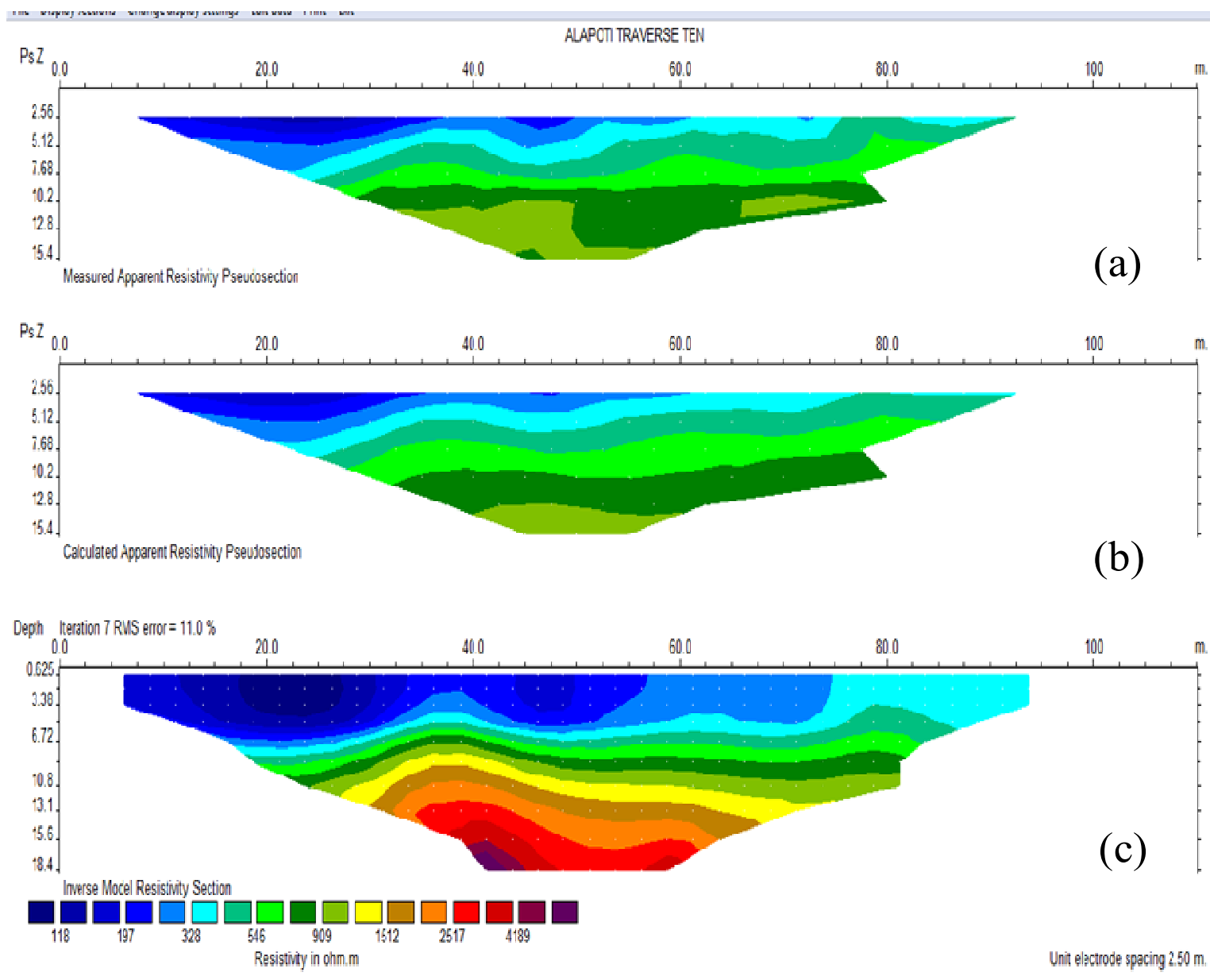

\section{$X$ unit electrode spacing $2.50 \mathrm{~m} \quad Y$ unit electrode spacing $2.50 \mathrm{~m}$}

Figure 12: (a) The measured apparent resistivity pseudosection, (b) calculated apparent resistivity pseudosection and (c) inverse model resistivity section for traverse 10.

Table 1 below shows the longitudes, the latitudes and the elevations of the midpoints of the ten traverses where the research was carried out.

Table 1: The bearings and elevations of the profiles/traverses.

\begin{tabular}{|c|c|c|c|}
\hline Traverse & Longitude & Latitude & Elevation (m) \\
\hline One & N006 $38^{\prime} 04.3^{\prime \prime}$ & E003001'54.6" & 47.12 \\
\hline Two & N006 $38^{\prime} 03.6^{\prime \prime}$ & E00301'55.1" & 47.52 \\
\hline Three & N006 $38^{\prime} 03.1^{\prime \prime}$ & E003015'5.4" & 49.74 \\
\hline Four & N006 $38^{\prime} 02.5^{\prime \prime}$ & E003001'55.7" & 44.01 \\
\hline Five & N006 $38^{\circ} 01.5^{\prime \prime}$ & E003001'56.1" & 40.93 \\
\hline Six & N006 $38^{\prime} 02.1^{\prime \prime}$ & $\mathrm{E} 003^{\circ} 01^{\prime} 54.0^{\prime \prime}$ & 43.86 \\
\hline Seven & N006 $38^{\prime} 02.5^{\prime \prime}$ & E003 $01^{\prime} 54.8^{\prime \prime}$ & 48.98 \\
\hline Eight & N006 $38^{\prime} 02.8^{\prime \prime}$ & E003 $01^{\prime} 55.5^{\prime \prime}$ & 51.48 \\
\hline Nine & N006 $38^{\prime} 03.2^{\prime \prime}$ & $\mathrm{E} 003^{0} 015^{\prime} 6.1^{\prime \prime}$ & 51.82 \\
\hline Ten & N006 $38^{\prime} 03.7^{\prime \prime}$ & E00301'56.9" & 54.78 \\
\hline
\end{tabular}

\section{SUMMARY AND CONCLUSION}

The data from each 2-D survey line was inverted independently with RES2DINV to give 2-D cross-sections with averages of 4.8 iteration and RMS error of $8.15 \%$. A contoured pseudosection conveys a qualitative two- dimensional resistivity variation with depth within the subsurface. The inversed model resistivity sections created models for the subsurface resistivity using an iterative smoothness constrained 
least square inversion and are interpreted to generate the subsurface geologic characteristics.

Results from 2-D inversed resistivity section showed that the second layer with resistivity value of about $200 \Omega \mathrm{m}$ to $600 \Omega \mathrm{m}$ and thickness of about $4.0 \mathrm{~m}$ is composed of lateritic clay. The third layer is made up of moderate laterite of thickness of about $3.0 \mathrm{~m}$ with apparent resistivity ranging from $600 \Omega \mathrm{m}$ to $1,000 \Omega \mathrm{m}$, and the fourth layer is suspected to be laterite sandy of apparent resistivity values of about $1,000 \Omega \mathrm{m}$ to $1,500 \Omega \mathrm{m}$ at a deep of about $12.0 \mathrm{~m}$.

\section{REFERENCES}

Adekunle, A., Ekandem, E. S., Ibe, K. E., Ananso, G. N., Mondigha, E. B., 2014. Analysis of thermal and electrical properties of laterite, clay and sand samples and their effects on inhabited buildings in Ota, Ogun State, Nigeria. Journal of Sustainable Development Studies, ISSN 2201 4268, Volume 6, Number 2, 391 - 412.

Barker, R. D., 1992. A simple algorithm for electrical imaging of the subsurface. First Break 10, 5362.

Barker, R. D., White, C. C. and Houston, J. F. T., 1992. Borehole siting in an African accelerated drought relief project In: E . P. Wight and W. G. Burgess, (eds). The hydrogeology of crystalline basement aquifers in Africa. Geological society special publication, 66:183 - 201.

Billman, H. G., 1976. Offshore stratigraphy and paleontology of the Dahomey embayment, west Africa. Proc. $7^{\text {th }}$ African Micropaleontological Colloquium

Dahlin, T. and Loke, M. H., 1998. Resolution of 2-D Wenner resistivity imaging as assessed by numerical modelling. Journal of Applied Geophysics, 38, 237 -249.
deGroot-Hedlin, C. and Constable S. C., 1990. Ocean's inversion to generate smooth two- dimensional models from magnetotelluric data. Geophysics 55, 1613-1624.

Edwards L. S. 1977. A modified pseudosection for resistivity and induced-polarization. Geophysics 42, 1020 - 1036.

Griffiths, D. H., Turnbull, J. and Olayinka, A. I., 1990. Two-dimensional resistivity mapping with a computer - controlled array. First Breaks 8, 121 $-129$.

Griffiths D. H. and Barker R. D., 1993. Two-dimensional resistivity imaging and modeling in areas of complex geology. Journal of Applied Geophysics 29, 211- 226.

Jones, N. A. and Hockey, R. D., 1964. Geology of some parts of Southwestern Nigeria, Geological Survey of Nigeria, Bull No 31, 1-101.

Kearey, P., Brook, M. and Hills, I., 2002. An introduction to geophysical exploration, $3^{\text {rd }}$ ed. Blackwell science, 262p.

Norton., 2000. Understanding pottery technique. New York Studio Vista Publisher,.102-115.

Okosun, E. A., 1990. A review of the cretaceous Stratigraphy of the Dahomey Embayment, West Africa, Cretaceous Research, 11, pp: 17-27.

Omatsola, M. E. and Adegoke, O. S., 1981. Tectonic Evolution and Cretaceous Strtigraphy of Dahomey Basin, Journal of Mineral Science, Vol. 18, pg 130-137.

Prudence, M. R., 1996. A source book on pottery analysis. University Press, Chicago, 9-50.

Tardy Yves, 1997. Soils. Spain. 105-110. 